\title{
The China model and its future ${ }^{*}$
}

\section{Yang Yao}

The Chinese economy's average growth rate of 9.7 per cent per annum from 1978 to $2008^{1}$ places China among just 13 successful economies that have managed to grow at a rate of 7 per cent or higher for 25 years or more since World War II (The Growth Commission 2008). Per capita gross domestic product (GDP) has grown by a factor of 12 in real terms to reach US $\$ 3400$ in $2008 .^{2}$ During this period China moved from a planned economy to a 'mixed economy' with the private sector now accounting for two-thirds of national GDP. How has China managed this profound feat?

One of the prevailing views regarding this question - especially since the financial crisis - seems to suggest that China has benefited from the authoritarian nature of its government; compared with a democratic government, an authoritarian government is able to mobilise large amounts of resources to tackle the most urgent bottlenecks blocking growth and institutional transition. Indeed, the issue is often framed in the context of the 'Beijing Consensus' versus the 'Washington Consensus' - the former being a model of authoritarianism and heavy state involvement in the economy, and the latter being a model of neoliberal and market-oriented doctrines. For example, this contrast has been clearly stated by Bruce Dickson, who has published influential works such as Wealth into Power: The Communist Party's embrace of China's private sector and 'Red capitalists in China: the party, private entrepreneurs, and prospects for political change' (Dickson 2010). Dickson believes that the Washington Consensus 'asserts that state intervention is not conducive to economic development, and that economic freedoms require political liberties associated with democracy to flourish. This neo-liberal model has been the cornerstone of international aid and lending programs for the past two decades.' In contrast,

An abridged version of this chapter has been published in Foreign Affairs Online under the title 'The end of Beijing Consensus' (2 February 2010, <http://www.foreignaffairs.com/articles/65947/the-end-ofthe-beijing-consensus $>$ )

1 The National Bureau of Statistics (NBS) website: <www.stats.gov.cn>

2 Ibid. 
the 'Beijing consensus' suggests that rapid economic development requires active leadership by political elites committed to growth and that authoritarian rule is necessary to sustain these pro-growth policies and limit demands for greater equity and social welfare. The Beijing Consensus therefore is antithetical to the Washington Consensus and has so far defied the logic that economic development inevitably leads to political change (Dickson, 2010: i)

This characterisation, however, neither captures the original meaning of the Beijing Consensus and the Washington Consensus nor stands the test of reality.

In Joshua Ramo's (2004) original formation, the Beijing Consensus comprises three elements - none of which is related to authoritarianism: 1) innovation; 2) equitable and sustainable development; and 3) self-determination. ${ }^{3}$ China's own history also rejects the thesis of pure authoritarianism and high levels of government involvement in regular economic activity. The Chinese government in the planning period was much more authoritarian and involved in the economy than it is now, but the whole period was characterised more by failures and even disasters than by successes. An authoritarian government might act more quickly than a democratic government, and this would more likely lead to disasters if its policies were wrong.

The Washington Consensus has also been misinterpreted since it was proposed by John Williamson in 1989. When it comes to economic transition, one of the misinterpretations is to treat the Washington Consensus as advocating fast transition and to compare it with the Beijing Consensus, which is often regarded as a model of gradualism. In the first place, Williamson (1990) did not say anything about the speed of transition, although he emphasised market mechanisms as the end result. On the other hand, China's gradualism has its roots in the country's recent history.

To be sure, China is unique in many ways. The Chinese leadership is unusually pragmatic, enabling it to succeed in a complex and constantly changing world. The Chinese transition has followed a gradual trajectory, allowing China to avoid the institutional and organisational disruptions that have plagued most other transitional economies. Equally, China's economic organisations lack the clear-cut features of a standard market economy, yet they have been adaptive in the evolutionary settings of the recent past. The list could go on; however, a serious examination of China's reform process raises the question of whether these features constitute a new model of economic growth or whether they are intermediate yet sometimes necessary steps towards the traditional model

3 Ramo's 'Beijing Consensus' itself can be debated. While self-determination can rightfully be used to describe China's dealings with other countries, China's economic growth can hardly be described as 'equitable' and 'sustainable' — nor is it driven by innovations. 
of a market economy. The Chinese leadership adopted a gradual approach to transition because of its aversion to the serious risks associated with fast transition. The Chinese Communist Party (CCP) made many serious mistakes during its first 30 years of rule: the grand experiments in social engineering including the aggressive collectivisation of agriculture, the Great Leap Forward and the catastrophic Cultural Revolution. With this legacy, the CCP saw a rapid transition to a full-blown market economy as a risky endeavour best avoided. At the same time, many of China's somewhat unconventional organisational forms can be understood as reactions to the unconventional political and economic circumstances encountered along its transitional path. For example, government ownership of township and village enterprises (TVEs), which was hailed by some as a challenge to conventional private ownership, was a consequence of the government's ambiguous - even conflicted - attitudes towards private firms in the 1980s. After private firms were made legal in the 1990s, TVEs vanished quickly (see Garnaut et al. 2005).

\section{A case for the Washington Consensus}

In terms of economic policy, China has not created a new model. Instead, it has followed closely the teachings of neoclassical economics. Indeed, if we make a list of the reforms that China has undertaken and then compare that list with the recommendations of the Washington Consensus - which in essence is a summary of policies that would be recommended by neoclassical economicswe might be surprised by the similarities in those two lists. In Williamson's (1990) original formulation, the Washington Consensus has the following 10 policy recommendations:

1. financial discipline to avoid an inflation tax

2. public expenditure redirected from redistribution to productive areas, such as primary education, health care and infrastructure

3. tax reform so as to broaden the tax base and cut marginal tax rates

4. financial liberalisation, involving an ultimate objective of market-determined interest rates

5. a unified exchange rate at a level sufficiently competitive to induce rapid growth in non-traditional exports

6. quantitative trade restrictions to be rapidly replaced by tariffs

7. abolition of barriers impeding the entry of foreign direct investment (FDI)

8. privatisation of state enterprises 
9. abolition of regulations that impede the entry of new firms or restrict competition

10. provision of secure property rights.

During the past 30 years, China has closely followed most of these recommendations.

In terms of fiscal discipline, the Chinese government has been very cautious in maintaining a roughly balanced budget. The rate of inflation has been kept in single digits in most years. On the expenditure side, pure redistributive programs have been kept to a minimum; central government transfers have been limited primarily to infrastructure spending. Before 2003, the share of 'social spending' in government budgets had been declining. It has slowly picked up in recent years, but its level is still low.

In terms of taxation, the overall tax burden-measured by the ratio of taxes to GDP_-declined dramatically from 31 per cent in 1978 to 12 per cent in 1993, largely because of fiscal decentralisation in the 1980s (Ramo 2004). The 1994 fiscal reform greatly strengthened the central government's taxation capacities, and the amount of government revenue has increased to approximately 24 per cent of GDP. This rate of growth of taxation revenue has, however, begun to concern the government and the general population. The rate of corporate income tax was reduced from 33 per cent to 25 per cent and the allowable deductions for personal income taxes have been raised several times. Even the value-added tax has begun to provide a deduction for capital investment.

On the international front, China has taken a road that leads decisively to the liberalisation of trade and FDI, although it has followed its own pace of opening up. Its special economic zones have served as windows for China to reach the outside world. The export-led growth model was adopted as a national development strategy in the mid 1980s. Joining the World Trade Organisation (WTO) in 2001 marked China's full integration into the world economy. Since then, China's trade dependence ratio - that is, the ratio of imports and exports to GDP - has been maintained at over 60 per cent, which is one of the highest among the large economies.

Domestically, two major themes of Chinese reform since the 1990s have been privatisation and deregulation. After 15 years of privatisation that started in the mid 1990s, most of China's state-owned enterprises (SOEs) have been released into private hands or transformed into publicly listed companies. Only a handful - though powerful - SOEs are still owned by the government. The removal of price controls happened even before privatisation. By the end of the 1990s, government reforms had removed many barriers to the entry and exit of individual firms in specific markets. 
Although protection of property rights is still weak in many arenas (especially intellectual property), China has made noticeable progress in the past 30 years. Several amendments to the constitution and the enactment of the Property Law have established a reasonable - though still incomplete-legal framework for property rights protection. The situation is far from perfect, but the direction has been set decisively for better and stronger protection in the future.

It is noteworthy that the Washington Consensus, as emphasised by Williamson, is different from the so-called 'neo-liberal doctrine' that adds to the list of capital account liberalisation, a floating exchange rate and, above all, the relentless working of the unbridled market, which China has clearly rejected. On the other hand, China has also adopted other policies frequently prescribed by neoclassical economics as essential for economic growth - among which the most significant are high saving and investment rates and an emphasis on primary education.

One area in which China has clearly not followed the Washington Consensus is in financial liberalisation. Interest rates are still controlled by the government. Despite vast deregulation, the State maintains tight controls on what it calls 'the strategic sectors' of the economy, such as petroleum, telecommunications and banking. Controlling interest rates is a tactic that the government believes is essential for its control of the financial sector. This controlled approach-even if it was warranted in the past-now, however, seems problematic. We will return to this point later.

The aim of China's three-decade-long economic reform has been clear-that is, to establish a functioning market economy. It is hard to imagine that China could have managed to grow at 10 per cent per annum without the introduction of the market. Some people might admit the importance of the market, but nevertheless believe that an authoritarian government is necessary to make the market work. This thesis has, however, been rejected by the failures of the Latin American dictatorships, particularly in Chile by Augusto Pinochet's regime of a mixture of military rule and the free market. At the minimum, it blurs the line between an authoritarian government and a regulatory government. Many governments in the industrialised world qualify as regulatory governments, but they are not authoritarian and do not have a heavy and direct hand in the economy. The analysis below will establish that an authoritarian government is not essential for a functioning market economy in China. 


\section{The disinterested government}

We have to ask a further question when we think about China's economic success more carefully: why has the Chinese government adopted the principles of neoclassical economics, particularly when the CCP still claims that Marxism is its ideological anchor?

The answer to this question, I suggest, is that the Chinese government has been a 'disinterested' government. Here the word 'disinterested' is used in one of its three meanings in aesthetics, ${ }^{4}$ which is 'detached' or 'unbiased' when one makes judgments on objective existences. Thus, a disinterested government is taken to mean a government that takes a neutral stance when conflicts of interest arise among different social and political groups. In other words, it is a government that does not consistently represent-and is not captured by-any social or political group in society. This does not mean that such a government is devoid of self-interest; quite the contrary. It can have not only its own interests, but be predatory towards society at large. The key is that its predation is 'identityblind' in the sense that it does not care about the social and political status of its particular prey. As a consequence, it is more likely to adopt growth-enhancing policies than is a government that consistently represents the interests of certain social or political groups.

To understand this assessment, consider that biased governments are obliged to adopt policies that consistently benefit their own favoured groups, and thus create a mismatch between productivity and government allocation of resources because other groups, not similarly favoured, might be more productive. In contrast, a disinterested government is autonomous in the sense that it is free of social and political constraints and is thus more likely to allocate public resources according to sector/group productivity. In that sense, a disinterested government promotes economic growth. It is willing to make this happen for two reasons. First, higher economic growth brings tangible gains (rewards) to its members. Second, higher economic growth brings satisfaction to the people, who in turn might be more willing to acknowledge its legitimacy.

A corollary of the above reasoning is that the policies adopted by a disinterested government are often selective and have the potential to enlarge income gaps in the society. Unless the gaps lead to serious threats to its rule, however, a disinterested government will have little incentive to correct them.

The Chinese government has acted as though it has been disinterested for the past 30 years. This started with the establishment of the 'growth consensus'

4 The other two meanings, according to Rind (2002), are 'uninterested' and 'without self interests' when a person examines an objective existence. 
at the end of the 1970s. This consensus came out of the CCP's realisation that continuing with Stalinist-style socialism would not only retard China's rise in the world, it would endanger its own legitimacy, which was already faltering in the mid 1970s. The need was to discourage growing discontent and put economic growth at the centre of all governmental and societal endeavours.

Looking back, it is clear that the Chinese government intentionally adopted selective policies to promote reform and economic growth - that is, policies that created winners and losers. China's integration into the world economy is a case in point. At the end of the 1970s, the United States was eager to bring China into its camp as a buffer against Soviet hegemony. China quickly grasped the opportunity. Yet that early adoption of the 'Open-Door Policy' was not without domestic resistance. The special economic zones enjoyed an abundance of preferential treatments that other parts of the country envied. The exportled growth model required that China embrace an unbalanced development path that encouraged rapid growth on the east coast and relative neglect of the interior; today, nearly 90 per cent of China's exports come from the nine coastal provinces. China's accession to the WTO in 2001 was also a selective move. Before accession, it was widely believed that China would have to undergo painful structural adjustments in agriculture, automobile manufacturing, banking, telecommunications and retailing if it were to join the WTO. Amid the debate, the central government actually sped up negotiations with WTO members, especially the United States. Despite many detrimental effects, accession to the WTO has greatly accelerated China's growth of exports. Between 2002 and 2007, Chinese exports grew by an annual rate of 28.9 per cent, compared with the average rate of 14.5 per cent in the previous decade. ${ }^{5}$

Privatisation of SOEs provides another case in point of a reform measure that was not welfare improving for every group in society. In the 1990s, during the most dramatic transformations, the CCP had to face new challenges emerging from an increasingly diversified population. Between 1995 and 2004-the peak of privatisation - nearly 50 million SOE workers lost their jobs. This put the CCP in a conundrum: by supporting privatisation it risked losing support from its main power base - the working class; on the other hand, its larger goal of transition to a market economy would be halted if it abandoned privatisation. The CCP finessed this difficult passage by quietly pushing continued privatisation while simultaneously doing all it could to re-employ laid-off workers.

Perhaps the most controversial illustration of the government's selective policies is the urban-rural divide. With urban per capita income standing at 3.5 times rural per capita income, China has the largest urban-rural income differential in the world. There are many explanations for this large gap, some of which are

5 The figures quoted in this paragraph are all from the NBS website: <www.stats.gov.cn> 
related to the institutional barriers inherited from the planning period. From an efficiency point of view, however, this large gap would not be bothersome to the government because cities enjoy much higher productivity and wages than can be found in the countryside.

The government has also been willing to correct mismatches between government resource allocation and the productivity of social groups. The dual-track price system instituted between 1985 and 1994 is a case in point. Under this system, SOEs were given the opportunity to sell their products and buy inputs in the emerging market after they fulfilled their planned quotas. While this system opened up a wide door for economic incentives to play a role in SOE decision making, the increasing gaps between market prices and quota prices created enormous scope for rent seeking. SOE managers and government officials who controlled the quotas of key inputs could easily get rich by selling their quotas to other enterprises and individuals. The brighter side of the dual-track system, however, was that it also created - unintentionally - new elements that benefited only from the market. The TVEs and private firms were particularly helped in this regard. They did not have access to planned resources such as bank credits and key inputs, but instead had to rely on the market to survive. Despite these perils, they had become important players in the Chinese economy by the early 1990s. For example, TVEs contributed 40 per cent to China's industrial growth and 40 per cent of its exports in the early 1990s (Lin and Yao 2001). These new circumstances forced the government to give up the dual-track system so TVEs and private firms were treated equitably with the SOEs. This happened even when the beneficiaries of the system were mostly powerful members of the CCP.

Government policy towards migrant workers is another example of the government's willingness to correct mismatches. Until very recently, free mobility of labour was hampered by various barriers including the household registration system (hukou), which is still in place today. In the 1990s, migrant workers were often treated as second-rate citizens deprived of basic rights to free mobility, workplace safety, health care and even equitable salaries. By the end of the 1990s, however, it had become clear that they were indispensable in the national economy as China became the 'world's factory'. It seems that urban dwellers had gained undue benefits with the government's suppression of migrant workers' rights, and the share of national income going to migrant workers fell below their relative contribution to the national economy. This unequal treatment ignited widespread grassroots rights movements and petitions by intellectuals. The CCP was alarmed by the potential for social unrest. Soon the discriminatory policies towards migrant workers began to wither away after the more equity-minded Hu Jintao-Wen Jiabao government took office in 2003.

The question remains why the Chinese government remained 'disinterested' during the reform era? The CCP's search for legitimacy is one of the major 
reasons. Despite its absolute power, the CCP has never been free to ignore the general wishes of the people. The April Fourth Movement in 1976, the June Fourth Movement in 1989 and numerous protests in subsequent years show that people are quite willing to stage organised resistance. In addition, fiscal decentralisation during the 1980s had considerably weakened the central government's authority over local governments, making it more prudent in carrying out regional policies. International monitoring has also played an important role. As it has emerged as one of the largest international players, China now must care about its legitimacy on the world stage. Since it is not democratically elected, the CCP does not have the legitimacy derived from the set of procedures approved by the people. As a result, it has to seek performancebased legitimacy - that is, legitimacy coming from the delivery of continuous improvements towards people's welfare.

Many other authoritarian regimes, however, also tried to obtain legitimacy through economic growth, yet they often did not enjoy power for long. It has a lot to do with the absence of extreme social inequality in China that the CCP has remained disinterested in the reform era.

In societies with extreme social inequality - such as many of those with authoritarian regimes - forming an alliance with the strongest social groups provides the best chance for the government to survive because those groups can provide sufficient resources for it to suppress any challenges from the unfavoured groups. The biased policies ultimately lead, however, to stagnation of economic growth and the erosion of the regime's legitimacy. In contrast, it is dangerous for the government in an equal society to side with any particular groups because other groups can form an alliance to block the governmentand perhaps even to unseat it.

China was made a socially equal society through a series of revolutions in the twentieth century. The 1911 Xinhai Revolution led by the nationalists ended the Manchu rule of imperial China and established a republic. The communist revolution of 1949 further levelled out Chinese society. Through comprehensive yet brutal land reform, the landed class was effectively eliminated and land distribution became equalised. Large businesses originally tied to the nationalist government were nationalised. By the early 1950s, the Mainland and Taiwan, despite their diametrically opposite ideological outlooks, were surprisingly similar in terms of social structure and government policies. Like the communists on the Mainland, the nationalists in Taiwan carried out a thorough - though peaceful-land reform. Both governments established SOEs and extracted surpluses from agriculture in the hope of speeding up the industrialisation process. Indeed, the Taiwanese industrial sector extracted more surpluses from agriculture through price cuts than its Mainland counterpart in the 1950s. Between 1951 and 1960, 27 per cent of Taiwan's capital formation came from 
net capital outflow from agriculture in the form of price cuts. ${ }^{6}$ In the same period, however, the Mainland government was in fact paying higher prices for agricultural products than the market (Wu 2001). The divergence occurred in 1956 when the Mainland began to eliminate family farming in the countryside and private businesses in the city. Between 1956 and 1978, the Mainland took a long detour and the reform has largely been a process of moving the country back on the track set for it in the early 1950s.

Political scientist Meredith Woo-Cumings (1997) has observed the linkage between an equal social structure and the government's neutrality with regard to society in East Asia. On the one hand, Taiwan and Korea were designated as suppliers of agricultural goods in Imperial Japan's version of the Great East Asian Commonwealth, so urban industrialists were suppressed in those two places. On the other hand, the Japanese colonists intentionally restricted the growth of the landed class in both places because they feared that this class would become a source of nationalist sentiments and organised upheavals against its colonial rule. Woo-Cumings (1997:331) writes: 'This discontinuity had a powerful leveling effect, equalizing incomes more than in most developing countries and providing a fertile ground for instituting effective interventionist states, which were given a relatively free hand to forge a developmental coalition as they saw fit.'

\section{The future?}

The selective and efficiency-biased policies have, predictably, led to large income inequality in China. The overall Gini coefficient has reached 0.47 (Cheng 2007) and the gap between the richest and the poorest is increasing even faster. Worse than that, governments at various levels constantly infringe on people's political and economic rights in order to create short-term growth. Arbitrary land acquisitions are but one example. Political and economic inequality has led to widespread protests in the country. In a sense, China is indeed a 'fragile giant', as Susan Shirk (2007) calls it. Yet it seems that there are no clear signs of an imminent collapse. How has the CCP managed to minimise the downsides of its selective policies?

First, the government has delivered continuous economic growth and rising living standards to the population. One of the curious things about China is that the government has constantly received an approval rating of 70 per cent or above, no matter who does the survey. ${ }^{7}$ The reason behind this is that the

6 Calculated from estimates provided by Lee (1971:Table 3, p. 29).

7 For a recent independent survey, see ISSS (2009). 
majority of the Chinese population is quickly moving into the rank of the middle class, who benefit from the current regime. In China, the middle class - at least for now - is not a force for change, but rather a force for stability.

Second, the government has carried out specific programs that quickly and effectively address early signs of discontent in the population. This includes an urban subsistence maintenance program that covers 20 million low-income people, re-employment centres that provide unemployment benefits to laid-off workers and train them for re-employment, several programs (for example, the Western Region Development Program) that aim to lower regional disparities and the recent New Countryside Movement to improve infrastructure, health care and education in rural areas.

Third, the government has gradually begun to give more respect to people's expressed interests in response to large-scale protests. The policy change for migrant workers is but one example. Other examples include the passage of the Property Law, increased levels of compensation for those who lose land and buildings to urban and industrial expansion and limited transparency of government budgets.

Lastly, the selective policies themselves have certain self-correcting effects. Being disinterested, the government does not consistently favour specific groups, so in the long run favours are likely to be distributed roughly equally - at least in areas where institutional impediments are relatively weak. For example, the Gini coefficients within the city and within the countryside alone are not high - both at the range of 0.35 to 0.37 - which approximates the levels found in South Korea and Japan (Cheng 2007).

Those measures are, however, only 'pain relievers' - being too weak to break down the institutional barriers and correct market imperfections that might stimulate new and threatening social groups. While the private business community is realising the importance of cultivating the government for larger profits, it is the government itself, its cronies and government-controlled SOEs that are quickly forming strong and exclusive interest groups. This is the result of the CCP's two political strategies to improve its chances of continuous control of the society. One is its transformation to become an all-people's party and the other is its intention to follow the Singaporean model to merge itself with the government. The first strategy is aimed at broadening its power base, while the second is aimed at controlling the country in the 'shell' of the government. China is, however, too big for the CCP to follow the Singaporean model even if it is a model worth pursuing. Being an all-people party means that the CCP gives up its political conviction to represent the working class. Since there are no other major political organisations in the country, society is left alone to develop along the trajectory dictated by a 'natural' process - that 
is, a process unmitigated by political contests - in which powerful groups are likely to accumulate more power and weak groups are likely to lose more power. Merging with the government could solve the CCP's organisational issues, but it will deprive it of the autonomy that it used to enjoy when it came to the fight between social groups because it is so involved in the economy that it can no longer avoid taking a biased stance. As a result, there is no assurance that the government can remain disinterested and growth will continue.

The situation has, however, worsened in recent years. In the past several years, government involvement in the economy has increased-most notably with the current CNY4 trillion (US\$586 billion) stimulus plan. Government investment helped China reach a GDP growth rate of nearly 9 per cent in 2009, which many applaud, but in the long run, it could suffocate the Chinese economy by reducing efficiency and crowding out more vibrant private investment.

The economy currently depends heavily on external demand, creating friction among major trading partners. Savings account for 52 per cent of GDP and consumption has dropped to a historic low. Whereas governments in most advanced democracies spend less than 8 per cent of government revenue on capital investment, this figure is close to 50 per cent in China. And household income as a share of national income is declining, making the average citizen feel poorer while the economy expands. As the Chinese people demand more than economic gains as their income increases, it will become increasingly difficult for the CCP to contain or discourage social discontent by administering the medicine of economic growth alone. ${ }^{8}$

More importantly, the government in its current form is cumbersome when dealing with multiple goals that are increasingly being demanded by society. Concerted efforts to promote GDP growth will still result in infringements to people's economic and political rights, which in turn will arouse periodic resistance. Despite its absolute power and recent track record of delivering economic growth, the CCP has still periodically faced resistance from Chinese citizens and, as already noted above, numerous protests have proved that the Chinese people are quite willing to stage organised resistance when their needs are not being met by the State. International monitoring of China's domestic affairs has also played an important role; now that it has emerged as a major global power, China is suddenly concerned about its legitimacy on the international stage.

All this suggests that some form of explicit political transition will be necessary to counterbalance the formation of strong and exclusive interest groups, to allow the government to deal with multiple goals and even to enhance the

8 The figures quoted in this paragraph are from the NBS website: <www.stats.gov.cn $>$ 
CCP's own rule. While the prospect of a multiparty and competitive democracy is not so clear at the moment, societal pressures are forcing the CCP to open up the political process. There is a silent yet steadily growing civil society movement pressing the government to show greater respect for people's rights. The Internet is serving as a platform not just for information sharing among concerned citizens, but for them to coordinate public protests against perceived government wrongdoing. The most powerful resistance, however, is likely to come from marginalised people and the 'rights movements' representing them. They are the people who suffer the most from arbitrary government infringements and benefit the least from the status quo.

The CCP must soon realise that there is no alternative to fuller democratisation if it wishes to maintain both high economic growth and enhanced social stability. The emergence of strong and privileged groups will block equal distribution of the benefits of economic growth in society, which will then render futile the CCP's strategy of trading economic growth for people's consent to its absolute rule. The CCP needs to act now to enable 'ordinary people' to challenge privileged groups on an open and institutionalised platform. Indeed, this will also ease the CCP's own task of controlling the bureaucracy because the democratic institutions will be able to do this instead. Although interest group politics is widespread and often damaging in democratic societies, an open and inclusive political process has been proven to be the most effective way to reach a balance between different groups. Indeed, this is precisely the mandate of a disinterested government - to balance the demands of different social groups. A democratic government can still be disinterested if the right institutions are in place to keep the most powerful groups at bay.

\section{References}

Cheng, Y. 2007, 'The Gini coefficient and its rural-urban decomposition since the reform', Chinese Social Sciences [in Chinese], no. 4, pp. 24-36.

Dickson, B. 2010, Who consents to the 'Beijing Consensus'? Crony communism in China, Manuscript, The Elliott School of International Affairs, George Washington University, Washington, DC.

Garnaut, R., Ligang S., Stoyan T. and Yang Y. 2005, China's Ownership Transformation: Process, Outcomes, Prospects, International Finance Corporation, Washington, DC.

Institute of Social Science Survey (ISSS) 2009, The China Report, Peking University Press, Beijing. 
Lee, T. 1971, Intersectoral Capital Flows in the Economic Development of Taiwan, 1895-1960, Cornell University Press, Ithaca, NY.

Lin, J. and Yao, Y. 2001, 'Chinese rural industrialization in the context of the East Asian miracle', in Joseph Stiglitz and Shahid Yusuf (eds), Rethinking the East Asian Miracle, The World Bank and Oxford University Press, Washington, DC.

Ramo, J. 2004, The Beijing Consensus: Notes on the new physics of Chinese power, Foreign Policy Centre, London, <www.fpc.org.uk>

Rind, M. 2002, 'The concept of disinterestedness in eighteenth-century British aesthetics', Journal of the History of Philosophy, vol. 40, no. 1, pp. 65-76.

Shirk, S. 2007, China, Fragile Superpower, Oxford University Press, New York.

The Growth Commission 2008, The Growth Report: Strategies for sustained growth and inclusive development, The World Bank, Washington, DC.

Williamson, J. 1990, 'What Washington means by policy reform?', in John Williamson (ed.), Latin American Adjustment: How much has happened?, Institute for International Economics, Washington, DC.

Woo-Cumings, M. 1997, 'The political economy of growth in East Asia: a perspective on the state, market, and ideology', in Masahiko Aoki, HyungKi Kim and Masahiro Okuno-Fujiwara (eds), The Role of Government in East Asian Economic Development: Comparative institutional analysis, Clarendon Press, Oxford.

Wu, L. 2001, 'A study of the size of the "price scissors" in China in 1949-1978', Researches in Chinese Economic History [in Chinese], no. 4, pp. 3-12.

\section{Acknowledgments}

I thank Daniel Bromley, Edward Friedman, Ashok Gurung, Yukon Huang, Sanjay Ruparelia and Jianying Zha for their helpful comments and suggestions. 